\title{
The Differentiation of Unique Education Services to The Superior Customer Value
}

\author{
Muhamad Adi Suja'i \\ Department of Islamic Banking \\ Sekolah Tinggi Agama Islam Sayid Sabiq Indramayu \\ Indramayu, Indonesia \\ bung.jai@gmail.com
}

\begin{abstract}
Education is a product in the form of educational services. The Presentation of those services includes physical aspects such as facilities and non-physical aspects such as the various forms of educational activities packaged in a single unit curriculum. Using differentiation, the product has a differentiator value from the other similar products. This research aims to analyze the influence of a unique educational service differentiation to the superior customer value for Islamic boarding-based junior high schools in Indramayu. This research method uses a survey of $\mathbf{1 0 0}$ respondents which are the students' parents/guardians. The result of this research is an educational service differentiation has a positive and significant effect to the superior customer value. For that presumably it should be best that Islamic boarding-based junior high schools constantly create the educational services differentiation so they are different and have a characteristic that is not belonged by other educational institutions.
\end{abstract}

Keywords-differentiation; unique educational services; Islamic boarding-based junior high schools

\section{INTRODUCTION}

One of the factors that affect the benefit of a product is differentiation. Differentiation is an effort made to keep the product would have a difference with competitors' products, either in terms of content, context, or infrastructure. Education is a product in the form of educational services. The Presentation of those services includes physical aspects such as facilities and non-physical aspects such as the various forms of educational activities packaged in a single-unit curriculum. Educational services have some characteristics: 1) more intangible than tangible; 2) production and consumption at the same time; and 3) lack of standards and uniformity [1].

As it is known that the educational institution has an activity that serves consumers, such as students, university students, and the general public, it is also known as "stakeholders." Educational institutions are essentially aimed at providing services. Parties served wish to obtain satisfaction from the services, because they have already paid quite high costs to educational institutions [2].

Educational institutions nowadays are taking the concepts of economics and business [2]. Management education is extremely important, where the growth and development of the institutions affected by the ability of administrators to perform scanning external environment, other institution competitors, and take into account the internal competency, it should be able to create a strategy that is capable of winning the competition without leaving the essence of education itself [1].

Product concept in the world of education is divided into educational services and graduates. The educational services themselves are divided on the services: curricular, research, development of social life, extracurricular and administration. The various forms of these products should be accordance with the market demand or market demand that is in line with the ability to purchase the educational services. Schools should be oriented to customer satisfaction. It also needs to look at shifting the concept of "customer benefit" to the "value" of the services that are deliverable. High-cost schools are not a problem along the benefits perceived by the students exceed the costs. Conversely, low costs schools are not guarantee will be invaded by the students if deemed they have low value [1].

The purpose of marketing is to make the products of companies or institutions become competitive because there is a different value among the competitors. It is true that the stronger the value of the difference; the better quality for the companies or institutions. In determining the differences, it is needed flair, precision and high creativity. The differentiation does not have to be elite, but the cultivated form of something that is rooted. It means that, the differences are excavated and born from local potentials - not something extraneous [3].

Differentiation is the act of designing a set of meaningful differences to distinguish the company's offer with the competitors. When physical products are not easy to differentiate, the key of success in the competition often lies in the addition of services that add value and boost the quality of the physical products. What distinguishes the service primarily is the ease of ordering, delivery, installation, customer training, customer consulting, maintenance and repair, as well as a few other things [4]. Four unique elements that distinguish the services of the goods are intangibility, inconsistency, inseparability, and supplies [5].

Implementing differentiation is an effective way of searching for the market's attention. From the many existing schools, parents will find it is hard to choose the schools for their children because the attributes of interest between schools increasingly standardized. Schools should be able to give a different pressure than the other schools in various forms of packaging that is attractive. Differentiation is a strategy giving different offers than the offers given by competitors. Differentiation strategy suggests companies to have a service 
or product that has a quality or function that can distinguish themselves with competitors. Differentiation strategy is implemented by creating perceptions of particular value to the consumers [1].

Differentiation becomes a very important strategy to enhance the competitiveness of educational institutions. Superior competitiveness will have an impact on the marketing achievements in the form of increasing public interest for the use of educational services. Increasing public interest to educational services marketing is not only the task of the educational institutions. It is stated that the best marketing in the world will not even be able to sell a bad product or that fail to meet the needs of everyone. The marketing department can only be effective if all sections and employees of companies have been designing and running a system in achieving customer value that is more superior to their competitors. The value for customers is the difference between the total customer value and the total customer cost [4].

\section{EDUCATION MODEL OF ISLAMIC BOARDING-BASED JUNIOR High SCHOOLS AS UNIQUE EDUCATION SERVICES}

Education from an Islamic perspective, as a long-life process and as an Islamic educational function, education should strive to teach and help students acquire the various aspects of knowledge within the parameters of Islam through the use of well-designed curriculum [6].

Education in Islamic boarding schools is called original and distinctive from Indonesia. This is because the Islamic boarding school education does not exist in countries other than Indonesia. Educational institutions like Islamic boarding schools commonly found in Hindu-Buddhist communities in India, Myanmar and Thailand. The Islamic boarding school was believed to be a native Indonesian education born of the acculturation process of a variety of Indonesian cultures itself [7]. In order to build the character of students, the Islamic boarding schools apply the various methods. The manual teaching in the form of bandungan, sorogan and memorizing has led their students to be able to face a wide range of social issues [8].

The characteristics of the Islamic boarding schools at least have five basic components, namely clerics, students, mosque, cottage, and the "Kitab Kuning". These five basic components are what distinguish Islamic boarding schools with other educational institutions. Along with the times, Islamic boarding schools have also experienced growth [7]. Islamic boarding schools are the educational institutions with dormitory systems, which provide facilities where educational institutions of learning as well as educational institutions in general, and the dormitory as a residence of students, as well as other facilities that can support the educational process [9].

Islamic boarding-based junior high schools are programs initiated by the Directorate of junior high school, the Directorate General for Primary and Secondary Education, Ministry of National Education in 2008. In general, Islamic boarding schools and schools are an educational unit, each of which has a distinct advantage to another. When walking alone there is potential and uncombined power of education. Thus was born the idea to combine the power of a comprehensive education. Birth of Islamic boarding-based junior high school program is based on the desire to combine excellence schools with excellence boarding schools. It is known that schools excel in science, technology, and various other general academic knowledges. Islamic boarding schools excel in terms of their faith and piety [7].

The work implemented by Islamic boarding schools in order to realize their role as an educational institution that combines general education and the material of madrasah, then the educational institutions combine the government curriculum and the studies of traditional religious. The clerics consider that the additional component in the form of education in order to develop the character is something very principle and important. By providing a common teaching materials, religious study, and character education, Islamic boarding schools create themselves as an educational institution in modern Indonesia [10].

The existence of Islamic boarding-based junior high schools aimed to enhance the integration between the values of Islamic boarding schools with the values that exist in the junior high schools. The basic principle of Islamic boarding-based junior high schools are: 1) Integrating intelligence quotient, emotional quotient and spiritual quotient; 2) Development of the concept of totality; 3) Plural and multicultural character; 4) nondiscriminatory; 5) Insight the benefits of local, regional and international; 6) Awareness of human rights; 7) Mastery "Kitab Kuning"; 8) Development of life-skills education; 9) School as an approach to education units; 10) Process of integrated learning (totality); 11) System of care; and 12) Learning system gives preferential treatment to students who have the ability on average [7]. The twelve basic principles of Islamic boarding-based junior high schools are the indicators in this research.

Differentiation is a core tactic which contains the efforts toward differentiation of content, context and infrastructure of the company's offer to the target market [3]. The result of the research revealed that the product differentiation is very significant influences to the customer value. This is because the number of competitors of similar business gives rise to the same or different product [11]. That there is an influence between product differentiation to customer satisfaction [12].

The customer total value is a combination of all grades of products, services, personals and images received by the buyer of the marketing offer [3]. The values, beliefs, and attitudes play a central role in consumer decision-making and related marketing actions [5]. In planning the market offers, marketers need to show five product levels. Each level gives customers more value added, and those five levels are customer value hierarchies. Those five levels are: 1) the basic level is the core benefit: the service or benefit of the customers actually bought; 2) on the second level, marketers need to change the core benefits into basic products; 3) on the third level, marketers set up the expected product, a set of attributes and conditions of buyers normally expect when they buy these products; 4) on the fourth level, marketers prepare the additional products exceed customer expectations; and 5) on 
the fifth level in the form of potential products, which include all the additional products that enable and products transformation or offers that are able to exist in the future. On the fifth level, companies are looking for new ways to satisfy customers and differentiate their offers [13].

\section{RESEARCH METHODOLOGY}

This research is a survey supported by tools of questioners that have been previously implemented the validity and reliability tests. The location of this study performed in Indramayu in November 2015. The population in this research is the students' parents/guardians at a private junior high school in Indramayu patterned Islamic boarding-based junior high schools. The total numbers of Islamic boarding-based junior high schools in Indramayu are 9 junior high schools.

The sampling method used was cluster random sampling. From 9 Islamic boarding-based junior high schools, the parents/guardians at 5 schools are sampled with considering of geographical location. The total respondents are 100 parents/guardians of students. From the five schools, each of them was taken a number of parents/guardians with referent to the percentage of the number students' total number in those five schools.

The five Islamic boarding-based junior high schools and the number of students' parents/guardians as the respondents are presented in the following table.

TABLE I. THE DISTRIBUTION OF RESEARCH SAMPLE

\begin{tabular}{|l|l|l|l|}
\hline No & $\begin{array}{c}\text { Name of Islamic Boarding- } \\
\text { based Junior High School }\end{array}$ & \multicolumn{1}{|c|}{$\begin{array}{c}\text { Schools } \\
\text { Location }\end{array}$} & $\begin{array}{c}\text { Numbers of } \\
\text { Respondents }\end{array}$ \\
\hline 1 & SMP Plus Miftahul Ulum & $\begin{array}{l}\text { Western } \\
\text { Indramayu }\end{array}$ & 25 \\
\hline 2 & SMP NU Darul Ma'arif & $\begin{array}{l}\text { Eastern } \\
\text { Indramayu }\end{array}$ & 26 \\
\hline 3 & $\begin{array}{l}\text { SMP Islam Al-Ishlah Boarding } \\
\text { School }\end{array}$ & $\begin{array}{l}\text { Central } \\
\text { Indramayu }\end{array}$ & 28 \\
\hline 4 & SMP Pesantren Urwatul Mutsqo & $\begin{array}{l}\text { Northen } \\
\text { Indramayu }\end{array}$ & 9 \\
\hline 5 & SMP Bayt Tamyiz & $\begin{array}{l}\text { Southern } \\
\text { Indramayu }\end{array}$ & 12 \\
\hline Numbers Of Respondents & \multicolumn{2}{l}{} \\
\hline
\end{tabular}

Data analysis was performed by analyzing the simple linear regression. Before doing the survey, the research questionnaire instrument has had a validity and reliability test to see whether worthy or not to be used as a data collecting tool. The data processing technique was done by the help of SPSS application program.

\section{RESULT AND DISCUSSION}

The characteristics of respondents in this research can be viewed by categories of age, gender, education level, income and employment. The respondents aged $36-40$ years by $37 \%$, aged $41-45$ years by $27 \%$, aged $46-50$ years by $14 \%$, aged $51-$ 55 years by $15 \%$, and aged $56-60$ years by $5 \%$. The gender includes $77 \%$ male and $23 \%$ female. The majority of respondents' education level is high school as much as $37 \%$, followed by $23 \%$ S.1, S.2 as elementary school and respectively $12 \%$, junior high school by $8 \%$, D. 1 as much as $2 \%$ and the remaining $1 \%$ respectively are educated D. 2 and S.3. The income level of the majority of respondents is 500,000 - 1,000,000 rupiahs by $43 \%$, followed by the level of income of $2,000,000-3,000,000$ rupiahs as much as $22 \%$, the level of income of $1,000,000-2,000,000$ rupiahs as much as $16 \%$, the level of income of 3,000,000 - 4,000,000 rupiahs as much as $10 \%$, the level of income of 4,000,000 - 5,000,000 rupiahs as much as $3 \%$, and the remaining $6 \%$ income of more than $5,000,000$ rupiahs per month.

The data has been collected, and then the distribution data was analyzed. The analysis results of the variable data frequency distribution in differentiation of Islamic boardingbased Junior High Schools Educational Services can be seen as follows.

TABLE II. DISTRIBUTION OF ISLAMIC BOARDING-BASED JUNIOR HIGH SCHOOLS EDUCATIONAL SERVICES DIFFERENTIATION VARIABLE DATA

\begin{tabular}{|l|l|l|}
\hline No & Name of Islamic Boarding-based Junior High School & $\begin{array}{c}\text { Average } \\
\text { Value }\end{array}$ \\
\hline 1 & Integrating IQ, SQ and EQ & 4,69 \\
\hline 2 & Development of the concept of totality & 3,85 \\
\hline 3 & Plural and multicultural character & 4,46 \\
\hline 4 & Nondiscriminatory & 3,85 \\
\hline 5 & Insight the benefits of local, regional and international & 3,77 \\
\hline 6 & Awareness of human rights & 4,62 \\
\hline 7 & Mastery "Kitab Kuning" & 4,85 \\
\hline 8 & Development of life-skills education & 3,92 \\
\hline 9 & School as an approach to education units & 4,54 \\
\hline 10 & Process of integrated learning (totality) & 4,31 \\
\hline 11 & System of care & 4,77 \\
\hline 12 & $\begin{array}{l}\text { Combining acceleration system in a-24hour-educational } \\
\text { activity }\end{array}$ & 3,63 \\
\hline
\end{tabular}

Table II shows the response data frequency all respondents on indicators of Islamic boarding-based junior high schools educational services differentiation variable data. On the table, it shows that the differentiation of educational services in the form of Mastery "Kitab Kuning" gets the highest perceptional rating with an average of 4.77 . The indicator combining acceleration system in a-24hour-educational activity gets only the lowest perceptional response of 3.63 .

The analysis results of the variable data frequency distribution of Customer Value are as follows. 
TABLE III. VARIABLE DATA DISTRIBUTION OF CUSTOMER VALUE

\begin{tabular}{|c|c|c|}
\hline No & Indicators & $\begin{array}{c}\text { Average } \\
\text { Value }\end{array}$ \\
\hline \multicolumn{2}{|c|}{ Educational Services Performances } & 4,04 \\
\hline 1 & Comprehensive Educational Services & 3,9 \\
\hline 2 & In accordance with the needs of society & 4,2 \\
\hline 3 & Sensitive to the times & 4,1 \\
\hline 4 & Well and Maximum Implementation & 4,0 \\
\hline \multicolumn{2}{|c|}{ Educational Services } & 3,88 \\
\hline 5 & Reachable and conducive location & 4,1 \\
\hline 6 & Comfortable physical facilities & 3,9 \\
\hline 7 & Informative Services & 3,9 \\
\hline 8 & Friendly & 3,9 \\
\hline 9 & Responsive & 3,8 \\
\hline \multicolumn{2}{|c|}{ Education Costs } & 3,98 \\
\hline 10 & Reachable costs & 3,8 \\
\hline 11 & Competitive costs & 3,5 \\
\hline 12 & Soft Financial Policy & 4,4 \\
\hline 13 & Scholarship facilities & 4,2 \\
\hline
\end{tabular}

From the three dimensions of customer value in the form of educational services performances, educational services, and the education costs in Table III above, it show that the respondents rate the performance dimension of education services gets the highest ratings of 4.04. In this dimension indicator of the educational services suitability to the needs of society gets the highest perceptional ratings with an average value of 4.2. As educational services comprehensiveness provided by Islamic boarding-based junior high school is still low. This is supported by the response data of the students' parents/guardians against these indicators, only get an average score of 3.9 and get the lowest score than the other indicators in this dimension.

The dimension of customer value getting a response with the lowest score is the dimension of educational services of only 3.88 with the indicator of responsive as the lowest indicator. Low ratings given by students' parents/guardians as the consumers of educational services to the education service indicates that the Islamic boarding-based junior high schools do not accordant to the consumer expectations, especially in terms of responsive services. The conduciveness of school locations as well as the reachable educational locations gets the highest rating. This indicates that Islamic boarding-based junior high schools are a good choice in determining the school location. Schools are rated to be on a favorable and reachable location.

As for the dimension of education costs, the indicator of competitive cost compared to other schools, respondents gave a low response of 3.5. The response value became the lowest valuation compared respondents' rates of other indicators. The uncompetitive education costs became the lowest perceptional rating from the customers of Islamic boarding-based junior high schools' education services. The students' parents/guardians considered that the costs make the schools are less able to compete with the similar educational institutions.

Based on the analysis results of simple linear regression with the help of SPSS application program, the correlation between the unique educational service differentiation in Islamic boarding-based junior high schools and the customer value of 0.492 . The correlation coefficient shows that between these two variables, they have a relationship with the medium criteria. This means that the size of the coefficient of the two variables has a medium relation. Then, the effect of a unique educational service differentiation in Islamic boarding-based junior high school to the customer value is $23.4 \%$, while the rest was influenced by other variables that are not examined in this research.

The regression coefficient is 0.541 , this means that if the differentiation of unique educational services is increased by one unit, then the customer value will increase by 0.541 units of value. Then Standardized Coefficients value of 0.492 indicates that the variable contribution of differentiation in Islamic boarding-based junior high school to customer value is by $49.2 \%$. With a coefficient value of probability or significance level of 0.000 , the differentiation of unique educational services has a positive and significant effect on the customer value. With these values, it can also be concluded that the regression model can be used to predict the variable of participation (customer value). The results are accordance to the results of Dora and Febriyanti that product differentiation is very significant influenced on customer value. This is caused by the number of competitors of similar business that gave rise to the same or different products [11].

\section{CLOSING}

\section{A. Conclusion}

Based on the research that has been done, and the exposure of the above discussion, this research can draw the following conclusion.

1) Differentiation of educational services in Islamic boarding-based junior high schools as a unique educational model that is measured through the indicators get a different perception from the students' parents/guardians as the consumers and customers of the educational services. The differentiation of educational services in the form of mastery "Kitab Kuning" gets the highest perceptional rating, while the indicator of combining acceleration system in a-24 houreducational activity gets the lowest perceptional rating. The dimension of customer value in the form of educational services performance gets the highest perceptional rating with the highest rating on indicator of suitability of educational services to the needs of society and the lowest rating on the indicator of the educational services comprehensiveness. While the dimension of educational services gets the lowest 
perceptional rating with the responsive indicator as the lowest indicators. It indicates that the Islamic boarding-based junior high schools cannot satisfy consumer expectations. As for the dimension of education costs, the indicator of competitive costs compared to the other schools gets the lowest perceptional rating. The students' parents/guardians considered that the costs set are too high compared to other schools. This makes these institutions are less able to compete with other schools in terms of affordability.

2) The differentiation of educational services in Islamic boarding-based junior high schools as a unique educational model affects the superior customer value. The amount of the contribution of this educational service differentiation on the customer value by $23.4 \%$ and the other $76.6 \%$ are influenced by other factors outside the education service differentiation variable.

\section{B. Recommendation}

In order to enhance the superior customer value to the educational institutions of Islamic boarding-based junior high schools from the perspective of education service differentiation, the author recommends the following things.

1) Educational institutions of Islamic boarding-based junior high schools need to optimize the unique characteristic as an educational program that combines the benefits of Islamic boarding education and junior high schools. The 12 peculiarities programs of educational programs which are unique and distinguish them from other educational institutions should be held optimally. When the uniqueness of Islamic boarding-based junior high schools worked optimally it will be an additional selling point for the institutions that will be able to create superior customer value in the eyes of customers and consumers.

2) The management of educational institutions should always initiate in order to bring the educational service differentiation. This effort is done to be able to create superior customer value for the educational institution. Differentiation of educational services will differentiate the educational institutions with the competitors. If the institutions have a superior characteristic that is not owned by the other competitors, it can be expected to create superior customer value for the institutions.

\section{THE WEAKNESS OF RESEARCH}

In this research, there is a weakness that the respondents are only from the consumers/customers the educational services of Islamic boarding-based junior high schools from the elements of students' parents/guardians who live around the schools. The students' parents/guardians who live far from the school, i.e. outside Indramayu, outside West Java and outside Java Island were not held due to the limited time and costs owned by the researcher. The regional distances of students' parents/guardians will certainly have a different preference in giving the perception of two variables in this study. The results of this research will be more accurate if the respondents involve also the students' parents/guardians who come from various regions, both far and near from schools.

\section{REFERENCES}

[1] V. R. Zainal, H. Kamal, and N. Muhammad, The Economics of Education: Mengelola Pendidikan Secara Profesional untuk Meraih Mutu dengan Pendekatan Bisnis, 1st ed. Jakarta: PT. Gramedia Pustaka Utama, 2014.

[2] B. Alma and H. Ratih, Manajemen Corporate \& Strategi Pemasaran Jasa Pendidikan: Fokus pada Mutu dan Layanan Prima, 2nd ed. Bandung: Penerbit Alfabeta, 2008.

[3] J. M. Asmani, Manajemen Efektif Marketing Sekolah, 1st ed. Yogyakarta: DIVA Press, 2015.

[4] P. Kotler, Marketing Management, 10th ed. New Jersey: Prentice Hall, 2000.

[5] R. A. Kerin and S. W. Hartley, Marketing: The Core, 6e ed. New York: McGraw-Hill Education, 2013.

[6] C. N. Hashim and H. Langgulung, "Islamic Religious Curriculum in Muslim Countries: The Experiences of Indonesia and Malaysia," Bull. Educ. Res., vol. 30, no. 1, pp. 1-19, 2008.

[7] Direktorat PSMP Dirjen Mandikdasmen, Era Mutu SMP, 2nd ed. Jakarta: Kementerian Pendidikan Nasional, 2010.

[8] I. Fikri, "Menggagas Grafologi Islam; Studi tentang Konsep Pengembangan Kepribadian dengan Pendekatan Tulisan Tangan Arab," in Annual International Conference on Islamic Studies (AICIS XII), 2012, pp. 1200-1221.

[9] S. Arifin, "Ma'had dan Riwaq: Sejarah Sosial Cikal Pendidikan Boarding School dalam Pendidikan Islam," J. Ilmu Tarb. "At-Tajdid," vol. 2, no. 1, pp. 1-11, 2013.

[10] R. A. Lukens-bull, "Teaching Morality : Javanese Islamic Education in a Globalizing Era,’ J. Arab. Islam. Stud., vol. 3, pp. 26-47, 2000.

[11] Y. M. Dora and R. A. M. Febrianti, "Pengaruh Diferensiasi Produk terhadap Nilai Pelanggan Brownies Kukus Amanda Bandung (Suatu penelitian terhadap Usaha Mikro Kecil Bisnis Keluarga Kue Brownies Kukus di Bandung-Jawa Barat)," Universitas Widyatama Bandung, 2011.

[12] K. U. Anastuti, Z. Arifin, and Wilopo, "Pengaruh Diferensiasi Produk terhadap Kepuasan Pelanggan (Survei pada Mahasiswa Pengguna iPhone di Universitas Brawijaya Malang)," J. Adm. Bisnis, vol. 7, no. 1, pp. 1-9, 2014.

[13] P. Kotler and K. Keller, Marketing management, 14th ed. New Jersey: Prentice Hall, 2012. 